\title{
No bull: genes for better milk
}

On 13 January, the US Department of Agriculture (USDA) launched a service that allows dairy-cattle breeders to double their chances of selecting the best bulls to sire milk-producing cows.

"This is the future of animal breeding," says Juergen Richt, a veterinary surgeon at Kansas State University in Manhattan.

For a decade, breeders who want to locate the best bull have the animals' semen tested for its DNA, looking for traits linked to milk quality and production. About a year ago, the leading

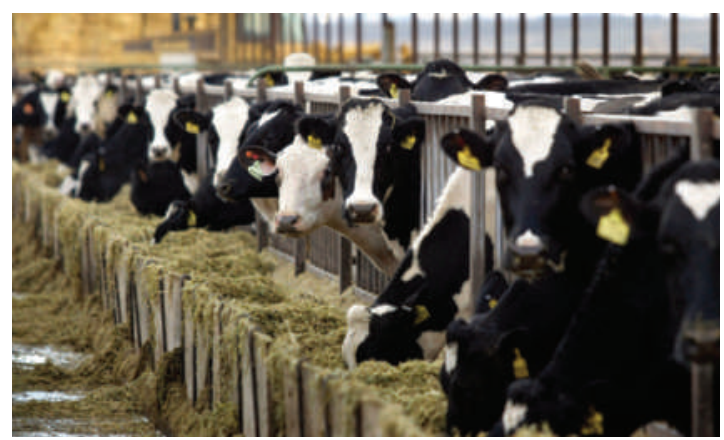

DNA testing can predict the best milk producers. artificial-insemination organizations in the United States and Canada funded a US \$1-million research project directed by Curtis Van Tassell, a geneticist at the USDA's Bovine Functional Genomics Laboratory in Beltsville, Maryland. Working with Illumina Inc. of San Diego, California, Van Tassell's team created a microarray chip containing 54,000 genetic markers called single nucleotide polymorphisms, or SNPs, that involve at least a dozen traits, including those known to affect milk quality and production.

Using high-throughput analysis, the researchers could then compare the DNA from a young dairy bull against the chip SNPs, telling breeders which bull would be likely to sire calves that were good milk producers. The test costs about $\$ 225$, and can be done when a bull $\cong$ is born, thus avoiding the $\$ 25,000-50,000$ cost of raising a bull for five years to see if it sires good milk-producing offspring. "The best bulls become elite breeders," says Van Tassell, "The others become hamburger."

Previously, DNA tests allowed a typical breeder to select the best bull some $35 \%$ of the time, says geneticist Ole Meland, vice-president of Accelerated Genetics in Baraboo, Wisconsin. The new technique identifies the best bull $70 \%$ of the time.

The US initiative is the first such nationwide programme. Companies in New Zealand and the Netherlands have set up private services for cattle breeders; and, following the USDA's lead, similar systems are being built by researchers at Aarhus University in Denmark, and in France and Australia.

Rex Dalton 